\title{
The Appearance of the Political Domination by the Fadeli Family in Lamongan Regency
}

\author{
Enrico Putra Pamungkas ${ }^{1}$, Aditya Perdana ${ }^{2}$ \\ \{enrico.putra@ui.ac.id'1, Aditya.perdana@ui.ac.id² \\ University of Indonesia, Depok, Indonesia ${ }^{1,2}$
}

\begin{abstract}
This article discusses the phenomenon of family politics in Lamongan, regarding the role of bureaucrats, politics, and various organizations related to family politics. Direct elections of regional chiefs (pilkada) and proportional electoral systems with the most votes have provided greater opportunities for political families to obtain and increase their abilities. Therefore, the number of family members occupying political offices is increasing. The focus of this research is the emergence of political dominance by the Fadeli family in Lamongan Regency. The data show that the family can utilize formal and informal political forces through clientelism strategies, which can lead to family dominance. The resources of family political dominance are the important element in interpreting family politics, based on Assako, Dal Bo, and Querobin [1]. This is also combined with the concept of clientelism strategy from Aspinall and Berenschot.
\end{abstract}

Keywords: Election, Local Politics, Family Politics, Political Dominance, Power.

\section{Introduction}

The collapse of the New Order regime after the reign of Soeharto for approximately 32 years have made the processes of democratization and decentralization a part of reforms in Indonesia. Democratization opens opportunities for citizens to participate in decision-making, including voting at the local level. Decentralization gives greater authority to regions to carry out its development. One of the implications of democratization and decentralization is the enactment of regional elections (pilkada) which began to be held since 2005 .

In line with the basic principle of decentralization is greater power sharing to local governments to plan and manage local development. According to Lili Romli [2], there were great expectations that accompanied the post-New Order decentralization policy, namely the consolidation of democracy and the improvement of government performance. With the hope that the public policy process can exist and be carried out at a smaller level, the opportunity of the community to participate in it can increase. Therefore, community participation can bring up democratic practices at the local level, and public participation can bring the practice of democracy to the local level. Accommodation of the interests and needs of the community will increase the level of acceptance of decisions made by the government (Prasojo et al., 2006, in [2]. However, to achieve such participation, there are of course basic requirements that must be present, such as local accountability that should be sufficient [2]. This is a fundamental limitation faced by many developing countries in implementing decentralization; it gives rise to cases related to decentralization that does not have a positive correlation with increased 
structural efficiency of the government at the local level. The change in decentralization can have an impact on increased political patterns at the local level that do not support democracy as well as better and more advanced government performance.

In some Southeast Asian countries, the absence of positive relationships among decentralization, democracy, and governance performance is characterized by the emergence of family policies that will lead to political dynasties at the local level. Pasan (2013) said that the emergence of political dynasties in the Philippines has weakened democracy. Decentralization and democracy are not marked with a positive correlation and political dynasty intensified with political developments, while election administration started to be implemented at the national and local level. The enactment of the Philippine constitution contains a prohibition on the existence of political dynasties in Chapter II Paragraph 26, but this still occurred in the Philippines presidential election. This is reinforced by a research conducted by Teresa and Eduardo Tadem (2016) on political dynasties that are eternal. The problems regarding political dynasties in the Philippines are derived from three basic factors. The first is the political and socioeconomic foundation that gives rise to political dynasties. The second is the inability to implement the provisions of the Philippine constitution effectively by enacting laws on political dynasties. The third is potential weaknesses that can oppose the existence of political dynasties.

Meanwhile, in the Indonesian political context, Aspinall and As'ad [3] explained that the implementation of decentralization further strengthened the position of local government leaders to try to spread family members and relatives in important government positions. There are also studies that see the emergence of the dominance of the Atut family in Banten and the Puang Wajo family in South Sulawesi (Nordholt and Klinken, 2007) and asserting that certain families with the resources they have can establish their dominance in their region, wherein decentralization has strengthened autocratic governance.

According to Ernesto Dal Bo [4], family politics occurs when a candidate has a familial relationship with other and/or previous candidates. This is further strengthened by the explanation of Pablo Querobin [1], who explained that family politics is a special form of elite efforts to maintain power, in which there are several family groups that monopolize political power. Asako [5] also explained that family politics would occur if one family member occupies a political position previously held by a relative. In a continuation, Aspinall and As'ad [3] stated that a political family could potentially become a political dynasty when the candidate is able to expand power. Therefore, once the dynasty founder loses position, the founder is replaced by a family member. This success can be intra-generational as in the case of the founder being replaced by spouses or siblings, or members of later generations such as children or sons- or daughters-in-law. Political families can strengthen political, social, and family networks in order to obtain great political support.

This article also examines the factors that influence the development of family politics in Indonesia that place family members in strategic positions, as in the research conducted by [6]. This article also analyzes political families from the perspective of clientelism as a strategy to expand the political family power. The analysis then refers to the theory of clientelism as a welfare program and development fund. According to Aspinall and Berenschot [7] the difference between welfare program and development fund can be seen in who the target recipient is. Welfare programs consider individual targets, while development funds are given to the community, not to individuals or for shared goods. These shared goods are an important media of exchange in Indonesia`s patronage democracy. Budget allocations to improve public infrastructure and basic facilities or development funds can be given through clientelism when a politician gives these funds to a region as a reward for support in both past and future elections. 
The family politics researched here is different from family politics in other regions, such as Banten and Wajo, where family politics has long occurred; the Fadeli family politics in Lamongan has only just emerged. There are several reasons why this article takes the case of Lamongan. First, considering historical aspects, Lamongan is not a former royal territory, so patron-client relations are difficult to develop. Second, Fadeli has a background as a bureaucrat who won the Lamongan elections in 2010. Third, the regent position that was won by Fadeli has made the opportunity for the family members of Fadeli to participate in the political contest in Lamongan with the bureaucracy, a soccer supporters group, and various businesses owned by the Fadeli family as political capital. This research is expected to be useful for similar research related to the study of family politics through family domination in formal and informal political forces.

\section{Methodology}

This research used the qualitative research approach, utilizing data and information that are collected from chosen sources that are considered capable of providing information and data to support this research. In addition, secondary data was also obtained from books, magazines, research journals, and other written materials related to the research topics, while primary data was collected by interviews.

Interviews were conducted regarding political experience, the recruitment process, and family support in the nomination process. Interviews with community leaders were conducted to obtain data related to the role of candidates in building relationships with community leaders. There were also interviews with people who managed to review candidate strategy to obtain votes in the election and win the political office of the Fadeli family in Lamongan. The quality of the candidates was also evaluated based on education, training, and political experience, both in party organizations and social organizations.

\section{Findings and Results}

In the context of this research, candidates utilized families who can move their political resources through family bases and organizations such as interest groups, political parties, and the government. This network can be an effective capital to become an elite or political figure.

The methods used by candidates to mobilize their political capital, especially family members, can be seen from the various potentials and structures that can be built by utilizing opportunities such as hierarchical structures, because social networks and elite actors from bridges of individuals and collectivity. Success in a position in the political environment is in the form of power that is very important to a political structure, in order to perform its functions and link networks in the social structure. Local elites used the networks in order to attract the public and show that the elites deserve to be followed because of the social and political capital that they have built over a long time.

Table 1. Fadeli Family Power in Lamongan Regency 


\begin{tabular}{|c|c|c|c|c|}
\hline No & Name & Non-Political Position & Political Position & $\begin{array}{l}\text { Family } \\
\text { Relation }\end{array}$ \\
\hline 1 & Fadeli & Bureaucrat, businessman & $\begin{array}{l}\text { Regent of Lamongan (2010- } \\
2015,2015-2020) \text {, Chairperson } \\
\text { of the Lamongan branch of the } \\
\text { Democratic Party }\end{array}$ & - \\
\hline 2 & Mahdumah & $\begin{array}{l}\text { Chairperson of Family } \\
\text { Welfare Development } \\
\text { (PKK) }\end{array}$ & - & $\begin{array}{l}\text { Wife of } \\
\text { Fadeli }\end{array}$ \\
\hline 3 & $\begin{array}{l}\text { Debby } \\
\text { Kurniawan }\end{array}$ & $\begin{array}{l}\text { President Director of PT } \\
\text { Persela Jaya, Managing } \\
\text { Director of Citra TV, } \\
\text { Chair of KNPI, and } \\
\text { Chair of IPSI Lamongan }\end{array}$ & $\begin{array}{l}\text { Legislator (Regional House of } \\
\text { Representatives [DPRD] of } \\
\text { Lamongan } \quad \text { House of of } \\
\text { Indonesian [DPR RI] } \\
\text { Representatives } \\
(2019-2024)) \text {, Chairperson of } \\
\text { the Lamongan DPC of the } \\
\text { Democratic Party (2017-2022) }\end{array}$ & $\begin{array}{l}\text { Second } \\
\text { child of } \\
\text { Fadeli }\end{array}$ \\
\hline 4 & Betty Nurfia & $\begin{array}{c}\text { Manager of Citra Medika } \\
\text { Hospital, Pharmacy } \\
\text { Manager of K } 24\end{array}$ & $\begin{array}{l}\text { Legislator of the Regional } \\
\text { House of Representatives of } \\
\text { Lamongan (2014-2019), Deputy } \\
\text { Chairperson of the Lamongan } \\
\text { DPC of the Democratic Party }\end{array}$ & $\begin{array}{l}\text { Third } \\
\text { child of } \\
\text { Fadeli }\end{array}$ \\
\hline 5 & $\begin{array}{l}\text { Sanditia Devis } \\
\text { Saputra }\end{array}$ & Doctor & $\begin{array}{l}\text { Legislator of the Regional } \\
\text { House of Representatives of } \\
\text { Lamongan (2014-2019), } \\
\text { Treasurer of the Democratic } \\
\text { Party in Lamongan }\end{array}$ & $\begin{array}{l}\text { Niece of } \\
\text { Fadeli }\end{array}$ \\
\hline 6 & Retno Wardani & Lecturer & $\begin{array}{l}\text { Chairman of the Lamongan DPC } \\
\text { Branch of the Lamongan DPRD } \\
\text { Democratic Party Strategy and } \\
\text { Policy Development Center } \\
(2014-2019,2019-2024)\end{array}$ & $\begin{array}{l}\text { Wife of } \\
\text { first son } \\
\text { of Debby } \\
\text { and Fadeli }\end{array}$ \\
\hline 7 & $\begin{array}{l}\text { Nahdlya } \\
\text { Kartika } \\
\text { Agustin }\end{array}$ & Entrepreneur & $\begin{array}{l}\text { Chairperson of the Lamongan } \\
\text { Parliament Election DPC } \\
\text { Branch of the Democratic Party } \\
\text { in Lamongan (2014-2019), } \\
(2019-2024)\end{array}$ & $\begin{array}{l}\text { Wife of } \\
\text { second } \\
\text { son of } \\
\text { Debby } \\
\text { and Fadeli }\end{array}$ \\
\hline 8 & $\begin{array}{l}\text { M. Arif } \\
\text { Anshori }\end{array}$ & Entrepreneur & $\begin{array}{l}\text { Deputy Treasurer III of the } \\
\text { Lamongan DPC of the } \\
\text { Democratic Party, Lamongan } \\
\text { DPRD (2019-2024) }\end{array}$ & $\begin{array}{l}\text { Niece of } \\
\text { Fadeli }\end{array}$ \\
\hline 9 & Noor Fathonah & Teacher & $\begin{array}{l}\text { Chairperson of the Lamongan } \\
\text { DPC of the Lamongan DPRD } \\
\text { Democratic Party Organization } \\
\text { Development Board (2014- } \\
2019,2019-2024)\end{array}$ & $\begin{array}{l}\text { Niece of } \\
\text { Fadeli }\end{array}$ \\
\hline 10 & $\begin{array}{l}\text { Yanuar Yudha } \\
\text { Prasetya }\end{array}$ & Entrepreneur & $\begin{array}{l}\text { Secretary of the Lamongan } \\
\text { KNPI and Lamongan DPC of } \\
\text { the Democratic Party, } \\
\text { Lamongan DPRD (2019-2024) }\end{array}$ & $\begin{array}{l}\text { Niece of } \\
\text { Fadeli }\end{array}$ \\
\hline 11 & $\begin{array}{l}\text { Siti Maskamah } \\
\text { Mursyid }\end{array}$ & Entrepreneur & $\begin{array}{l}\text { Deputy Treasurer I of Lamongan } \\
\text { DPC of the Democratic Party, }\end{array}$ & $\begin{array}{l}\text { Relative } \\
\text { of Fadeli }\end{array}$ \\
\hline
\end{tabular}




\begin{tabular}{|l|l|l|l|l|}
\hline & & & $\begin{array}{l}\text { Lamongan DPRD (2014-2019, } \\
\text { 2019-2024) }\end{array}$ & \\
\hline
\end{tabular}

\subsection{The Political Strategy of Fadeli in Winning the 2010 Lamongan Regional Election}

Much of the literature discusses running political dynasties without definition, perhaps because the family is assumed as a natural unit of social analysis. In political discourse in Indonesia, the term "political dynasty" has been widely applied. Therefore, family groups involved in politics are quite varied, and so are the various kinds of powers and roles given to family members [3]. However, the case of family politics in Lamongan is different from the cases in Banten and Wajo. The politics of the Atut family in Banten shows how decentralization has led to political elites who have the opportunity to further strengthen and expand their power. Local political power in Banten is predominantly due to the shifting of the interaction between local state actors (local government elite) and societal actors (winners-entrepreneurs) [3]. The case of family politics in Wajo was influenced by the government during the kingdom. This creates a patron-client relationship that is still developing today, thus affecting local politics characterized by inter-ethnic competition between the Bugis and Makassar ethnic groups. Whereas, in Lamongan the existence of a decentralized system did not immediately create family politics, but after 10 years of running, the family of Fadeli emerged as an elite with a bureaucrat background.

Therefore, through various experiences, Fadeli benefited while competing in the 2010 regional election. Fadeli also received support from government officials, given his background as a former bureaucrat; as much as $90 \%$ of bureaucrats joined to make Fadeli successful in becoming the Regent of Lamongan. In fact, he also received support from local political elite, who are quite critical (Sa'adah 2013). Fadeli also used various types of media such as radio, television, and newspapers to spread his campaign [8]. Among new voters, Fadeli prefers youths from among the supporters of the local football (soccer) team, Persela Lamongan, who are called LA Mania; they became very beneficial to be used as support in politics. Fadeli, who was once the daily chair (manager), later became close to supporters in helping to advance Persela Lamongan. The number of supporters proved to be very effective in supporting Fadeli in the political contest [8]. The success of Fadeli in attracting Persela supporters as the main commodity to be elected as the regent can be considered cunning.

Fadeli also has the advantage of having a number of businesses in Lamongan. For example, he has a company named CV. Sumber Rezeki in the business of supplying office stationery to all regional task force offices (SKPD) in Lamongan. Fadeli also owns a Naff karaoke house business. One of his children, Betty Nurfia Puspita, manages Citra Medika Hospital and K24 Pharmacy. The ownership of businesses by the family contributes to the economic sector owned by Fadeli in Lamongan politics [8].

These networks allow Fadeli to have a strong capital for the 2010 Lamongan Regency regional election. Fadeli then nominated himself as a regent candidate with Amar Syaifuddin, supported by the four political parties of PAN as the incumbent party, PKB, Golkar, and the Democratic Party. The three other pairs of candidates were Suhandoyo - Kartika Hidayati, supported by PDIP and PKB; Tsalist Fahmi - Subagio, supported by PKNU, PPP, Hanura, and Gerindra; and Ongky - Basir Stikno, running independently [9]. Amar Syaifudin as the candidate for deputy regent was a suitable choice, considering that Amar had a lot of political experience in Lamongan. 
The 2010 Lamongan Regency regional election was won by Fadeli - Amar Syaifuddin ("FAHAM") with 253,997 votes, followed by the candidate pair of Suhandoyo - Kartika ("SEHATI") with 238,816 votes. The other candidate pairs of Tsalist - Subagio Rahmat ("SAHABAT") won 90,029 votes and Ongky - Basir (“OBAMA") won 37,993 votes [9]. The victory of Fadeli and Amar Syaifuddin as Regent and Deputy Regent was inseparable from the very solid coalition of political parties and support by the incumbent political party of PAN, which was willing to support Fadeli-Amar as candidates for Regent and Deputy Regent of Lamongan in 2010 .

\subsection{Map of the Political Family of the Lamongan Regent}

A political family consists of more than one family member of a family that has managed to gain political positions such as executive and legislative positions of certain regions, including districts and provinces. According to Aspinall and As'ad [3] , a political family can become a political dynasty if a candidate is able to expand power continuously so that if the founder of the dynasty loses a position, a family member will replace the position. Efforts to expand power also occurred in the politics of the Fadeli family, which first occurred when Fadeli intervened to make the second child of Debby Fadeli the president director of PT Persela Jaya. It became very important to regulate everything in the internal agency of Persela [10]. The fanaticism of LA Mania as the main supporter group of Persela was used by Fadeli to support him in the 2010 Lamongan Regency regional election, for which as a result Fadeli was elected to his first term as Lamongan Regent.

Fadeli also tried to instate Debby as the DPC Chairman of the Democratic Party in Lamongan. Debby Kurniawan was finally elected as the Chairperson of the Democratic Party DPC during the Regional Consultation (muscab) at the Handayani Building, Lamongan Education Office [11]. After becoming the Chairperson of the Democratic Party DPC of Lamongan, Fadeli intervened yet again to ask Debby to become the Chairperson of the Lamongan Indonesian Youth National Committee (KNPI), and finally he succeeded in becoming the Chairman of the Lamongan KNPI for the 2013-2016 term.

They insisted on strengthening the relationship by consolidation to all branches of the Democratic Party in Lamongan in the villages. After using party branches in the village, the Fadeli family members began to be introduced in other roles in the 2014 Lamongan legislative election through the Democratic Party. This is what led the Fadeli family to become involved in politics. The placement of the Fadeli family members in strategic positions as legislators from the Democratic Party was realized in 2014, resulting in seven Fadeli family members occupying ten Democratic Party seats in the Lamongan DPRD, which consisted of Debby Kurniawan and Bety Nurfia Puspita (two biological children of Fadeli), Retno Wardhani and Nahdliyah Kartika Agustin (then-children-in-law of Fadeli), and Sanditiya Devis Saputra, Noor Fatonah, and Siti Maskamah (relatives of Fadeli and husband of the Head of Department in Lamongan) [9].

The Fadeli family contested politics from five electoral districts, including electoral district 1 by Bety Nurfia with 15,815 votes and Siti Maskamah with 4,442 votes, electoral district 2 by Retno Wardhani with 15,399 votes and Sanditiya Devis with 5,883 votes, electoral district 3 by Noor Fatonah with 6,610 votes, electoral district 4 by Nahdliyah Kartika with 7,603 votes, and electoral district 5 by Debby Kurniawan with 9,883 votes (KPUD Lamongan). All members of the Fadeli family are from the Democratic Party and became a trend for the creation of political dynasties. This is inseparable from the figure of Fadeli, who at that time had become the Regent of Lamongan. 
The 2014 election was an opportunity for Fadeli to expand his power. The Fadeli family members succeeded in gaining control of Regional People's Representative Assembly seats and decreased control of intense critics to the executive. The change benefited Fadeli to become a personal interest through policies such as government budget and projects. It was as if they had planned for the corruption case that caught those related to Fadeli as the Regent. There was planning for funding the 2014 election campaign using government funds. The Corruption Hunters Association (LPPK) had reported allegations of corruption in the Lamongan Regency Government environment, including an alleged corruption case in Lamongan Plaza by PU Cipta Karya worth Rp. 15.6 billion. Persela and KONI granted funds amounting to Rp 118.46 billion and allegations of corruption ceased without being continued by the prosecutor [12].

The appearance of the Fadeli family members as legislative candidates has been criticized by various parties. Some mentioned that because they received facilities from the government, the regent also had the authority to put his family members in the regional legislative assembly. This was revealed by the Head of the UPT Agriculture Office of Lamongan Regency to the media, who explained the existence of instructions to all bureaucrats to allow victory by Democratic Party candidates, which included children, in-laws, and relatives of Fadeli [13]. Those who do not support this are threatened to be transferred or will have complications in the assistance of agricultural equipment from the UPT Agriculture Office of Lamongan Regency. Then, during the distribution of the agricultural equipment, it is obliged to inform the farmers that the tools are a personal gift from Regent Fadeli and they must support the Democratic Party. Apart from the various polemics, of the 10 seats won by the Democratic Party in the Lamongan DPRD, the Fadeli family members indeed successfully filled seven of them. The success of the Fadeli family in winning the 2014 election was due to the role of Fadeli and the help of the bureaucrats in Lamongan. The hopes of Fadeli in having family members win in the 2014 legislative elections will be able to affect the 2015 elections, since Fadeli will be the incumbent in the election.

Aspinall and Berenschot [7] describe that the incumbent status provides benefits for practices of clientelism through public spending. They explained that there were at least a number of mechanisms such as welfare programs, development funds, awarding of government project contracts, and politicizing bureaucracy. Aspinall and Berenschot [7] state that this pattern shows the characteristics of a patronage network centered on the state, where incumbents have relatively strong discretionary powers and which still exists in the reform era. Some of the advantages of incumbent candidates become strong capital for achieving victory in elections. The various benefits include the work of the incumbent that can already be felt and enjoyed by the community, causing popularity to increase. Fadeli as the incumbent candidate in the 2015 Lamongan regional election had built and embraced farmers as the driving force of his political backers through policies that benefit farmers [9]. Financially, the incumbent candidate commuted costs because the regional task force office tends to run the programs of the incumbent and $95 \%$ of the backers of the regent did not use personal costs [14]. Therefore, Fadeli as the incumbent candidate during the campaign will make every effort to show the variety of successes to convince voters in the presentation of programs that succeed them.

At the time that registration opened for candidates of Regent and Deputy Regent, three pairs of candidates registered with the Lamongan Regency Election Commission. The three pairs of candidates are Mujianto - Sueb ("JOS") as number 1, incumbent candidate Fadeli - Kartika Hidayati ("FAKTA") as number 2, and Nursalim - Edi Wijaya ("SAE") as number 3. Of the three pairs of candidates, the backing coalition of Fadeli and Kartika was the largest coalition. The grand coalition consisted of nine political parties: PPP, PAN, PKS, PKB, PDI-P, Hanura, Democrat, Golkar, and Gerindra. Fadeli and Kartika, who were candidates for regent and vice 
regent, caught the attention of the public, because they were political rivals in the 2010 Lamongan Regional Election.

Based on the results of the vote tally for the Lamongan Regency election as conducted by the Lamongan District Election Commission, the candidate pair of Fadeli and Kartika came out as the winner with 448,833 votes. For the other candidate pairs, Mujianto - Sueb had 16,191 votes and Nursalim - Edi had 165,877 votes. On that occasion, the Lamongan Election Commission also invited candidates who were dissatisfied or cheated to immediately report to the Constitutional Court. If the other candidate pairs did not go to court, the vote count results from the Lamongan Election Commission would be reported to the leadership of the Lamongan Regency Local Parliament in order to conduct an immediate inauguration for the elected pair of Regent and Vice Regent candidates [9].

The role of the son of Fadeli as the Chairperson of the Lamongan Democratic Party DPC became stronger. The Lamongan Democratic Party DPC was increasingly dominated by the Fadeli family after the re-election for the 2017-2022 term as appointed based on the Decree of the Democratic Party DPP Chairperson Number 46/SK/DPP.PD/VI/2017 with Debby Kurniawan as Chairman of the Lamongan Democratic Party DPC, Bety Nurfia as Deputy Chairman I, Sandiana Devis (the fourth child of Fadeli) as Treasurer, Yanuar Yudha Prasetya (nephew of Fadeli) as Secretary, Retno Wardhani (wife of Debby) as Chair of the Center for Strategy and Policy Development, Nadia Kartika (wife of the first son of Fadeli) as Chair of the Election Commission, Anshori (nephew of Fadeli) as Deputy Treasurer III, Noor Fatonah (nephew of Fadeli) as Chair of the Organizational Development Agency, and Siti Masama (a relative of Fadeli) relatives as Deputy Treasurer I. Fadeli himself served as the Chairperson of the DPC Branch of the Democrats. This will then lead to a political dynasty through political domination by the family. According to Aspinall and As'ad [3], political dynasties in Indonesia further weaken political opportunities for the public to enter the domains of political office and the phenomenon that occurs in political dynasties is actually supported by political parties.

The political development of the Fadeli family in the 2019 legislative election was slightly different due to the withdrawal of the third child of Fadeli from political contest. However, the resignation of Bety did not dampen the spirit of the nephew of Fadeli to advance in political contest. The strategy remained the same through the Democratic Party, with Yanuar as the nephew of Fadeli. One difference was that Debby was able to win a seat in the Indonesian National Parliament in the 2019 legislative election. Politics of the Fadeli family still showed existence with the election of Fadeli family members from the five electoral districts in Lamongan. Control of all electoral districts also became capital to sustain Debby in the Indonesian Parliament. With this, elections for the People's Representative Assembly at the regional and national levels became increasingly used by Fadeli family members in implementing a tandem strategy in which candidates from Fadeli family members will campaign simultaneously because there are still many constituencies in the Lamongan area.

Utilization of votes from the KNPI is also a political capital possessed by Debby Kurniawan as Chairman of the Lamongan KNPI to win a seat in the Indonesian Parliament from the Democratic Party through the Lamongan-Gresik electoral district. KNPI is an organization that is already well-known in Lamongan because it is often with the people to carry out social assistance and other activities. The success of the Fadeli family in choosing KNPI as political backing is very appropriate because the people are familiar with KNPI and its activities. With KNPI active in various activities in Lamongan, it has given a variety of considerations to the people about the importance of organizing to support progress for the Lamongan community. The various activities include social assistance, music events, sports competitions, and coaching. Each of the various activities always includes a photo of Debby as the chair of KNPI, 
which is aimed to provide legitimacy of the success of KNPI in allowing youths to participate and follow the activities. The gathering of KNPI masses through various activities can reach villages, by channeling the talents of village youths to increase the active role of KNPI. The success of KNPI at the sub-district and village levels is due to funding from the Lamongan Regency Budget for the KNPI. Aspinall and Berenschot [7] explain that politics by clientelism could involve benefits provided through distributed private or state resources because of a government policy. Politics by clientelism does not concern the type of benefits or offered benefits, but the creation of relationships that determine the offer of benefits. The characteristics of clientelism is shown through development funds, given in the form of shared goods to certain communities as gifts for support in the general election.

The 2019 legislative election also adopted the same strategy of using LA Mania for political support, including the desire of supporters wanting to renovate the Surajaya Main Stadium because the capacity of the stadium could no longer accommodate the number of supporters during the match. Through the regional budget, Fadeli and Debby can pass the development project to the Department of Public Housing and Area Settlement. However, this development has a hidden importance. The project was started at the end of 2017 and was targeted to be completed at the end of 2018 [15]. The hope is that the construction of the stadium can change political support because it approached the 2019 legislative election. This would create emotional closeness with LA Mania supporters and reinforce that the construction of the stadium was assisted by Fadeli and Debby as holders of positions at PT Persela Jaya, even though the construction of the stadium used funding from the local government of Lamongan. Aspinall and Berenschot [7] stated that clientelism through development funds is carried out by elected executive governments and legislative members through a strong push to use development funds for their own benefit in elections.

\section{Conclusion}

The phenomenon of family politics can be said to be increasing in terms of political offices in the legislative and executive positions. Family politics itself can occur at the national or local level. At the local level there are the family politics such as in Banten and Wajo. The phenomena of family politics in Banten and Wajo are family politics that have long occurred. In contrast to the two regions, the phenomenon of family politics in Lamongan is relatively new. This started with the election of Fadeli as the Regent of Lamongan Regency, who then created opportunities for other family members to attain strategic positions in Lamongan.

The existence of family politics is increasingly seen when the Fadeli family members possess important internal positions in the Democrat Party as the chair of the party branch, which then has a large number of backers in the area. The position of the Fadeli family is also stronger as the network developed through interest groups and communities, which then became political support for Fadeli family members to win the 2014 and 2019 legislative elections, and for Fadeli to become the regent of Lamongan in the 2015 elections. Ownership of power in the regions builds up the seeds of political dynasties, which can be seen from the various sources of power possessed by family and close relatives. The retention of power by Fadeli is assisted by the existence of a power network consisting of the main network and supporting networks that have been formed and can competently work to be placed in strategic positions. This then creates the political dominance of the Fadeli family in Lamongan. Family politics in Lamongan has shown how the Fadeli family increasingly expanded power by means of clientelism strategies for the purpose of maintaining political support. Through clientelism strategies in the form of 
welfare programs and development funds, the role of the Fadeli family has shown indications of power with the help of bureaucrats, youth organizations, communities, and political parties.

\section{References}

[1] P. Querubin, "Political reform and elite persistence: Term limits and political dynasties in the Philippines," in APSA 2012 Annual Meeting Paper, 2012.

[2] L. Romli, "Jawara dan Penguasaan Politik Lokal di Provinsi Banten (2001-2006)," Ringkasan Disertasi S-3 pada Progr. Pascasarj. Ilmu Polit. Fak. Ilmu Sos. dan Ilmu Polit. Univ. Indones. Depok, 2007.

[3] E. Aspinall and M. U. As'ad, "The patronage patchwork: Village brokerage networks and the power of the state in an Indonesian election," Bijdr. tot taal-, land-en volkenkunde/Journal Humanit. Soc. Sci. Southeast Asia, vol. 171, no. 2-3, pp. 165-195, 2015.

[4] P. D. B. dan J. S. Dal Bo, E., "Family Matters: The Prevelence and Effects of Political Families in National Politics," University of Misssouri.

[5] Y. Asako, T. Iida, T. Matsubayashi, and M. Ueda, "Dynastic politicians: Theory and evidence from Japan,” Japanese J. Polit. Sci., vol. 16, no. 1, pp. 5-32, 2015.

[6] M. Sukmajati and E. E. Aspinal, "Politik Uang di Indonesia," Polgov: Yogyakarta, 2014.

[7] W. Aspinall, E., \& Berenschot, Democracy for Sale: Pemilihan Umum, Klientelisme, dan Negara di Indonesia. Yayasan Pustaka Obor Indonesia, 2019.

[8] I. S. Permatasari, "Strategi marketing politik pasangan Fadeli dan Amar Saifudin (Faham) dalam menggalang dukungan warga NU pada Pilkada Lamongan Tahun 2010.” IAIN Sunan Ampel Surabaya, 2011.

[9] H. Mahfiroh, "Cikal Bakal Politik Dinasti Fadeli," Universitas Airlangga., 2017.

[10] P. Jatim, "Keluarga Fadeli 'rakus' Jabatan," 25 November 2011. .

[11] H. Manshuri, "Putra Bupati Lamongan Pimpin Demokrat," 7 June 2012. [Online]. Available: https://surabaya.tribunnews.com/amp/2012/06/07/putra-bupati-lamongan-pimpin-demokrat [Accessed: 15-May-2019].

[12] "Fadeli Diduga Punya Agenda Tersembunyi," 2 May 2014. [Online]. Available: https://surabayapagi.com/read/114115/2014/02/fadeli_diduga_punya_agenda_tersembunyi.html . [Accessed: 19-Jun-2019].

[13] M. Ridwan, "Enam Anggota Keluarga Bupati Dipastikan Duduk di DPRD Lamongan," 20 April 2014. [Online]. Available: https://lensaindonesia.com/2014//04/20/enam-anggota-keluargabupati-dipastikan-duduk-di-dprd-lamongan.html/amp . [Accessed: 19-Jun-2019].

[14] G. Arganata, "STRATEGI PEMENANGAN PASANGAN INCUMBENT PADA PEMILUKADA SERENTAK TAHUN 2015 di KABUPATEN LAMONGAN (Studi pada pasangan Fadeli dan Kartika Hidayati)." University of Muhammadiyah Malang, 2018.

[15] Kumara, "Kabar Gembira Untuk Suporter Setia Persela," 13 January 2017. [Online]. Available: https://juara.bolaspot.com/amp/read/321513941/kabar-gembira-untuk-suporter-setia-persela/. [Accessed: 19-Jun-2019]. 